NASA Technical Memorandum 80114

\author{
NASA-TM-80114 19790018256
}

EFFECTS OF TRUNCATION OF A PREDOMINANTLY COMPRESSION LOAD SPECTRUM ON THE LIFE OF A NOTCHED GRAPHITE/EPOXY LAMINATE

Edward P. Phillips

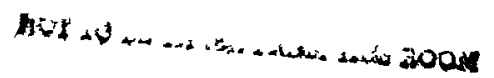

June 1979

\footnotetext{
N/SA

National Aeronautics and

Space Admınistratıon

LIBRARY BgDY

$$
\begin{gathered}
43-20-75 \\
\text { LANGLEY RESEARCH CEIYTER } \\
\text { LIBRARY, NAEA } \\
\text { HAMFTON, VIRGINIA }
\end{gathered}
$$




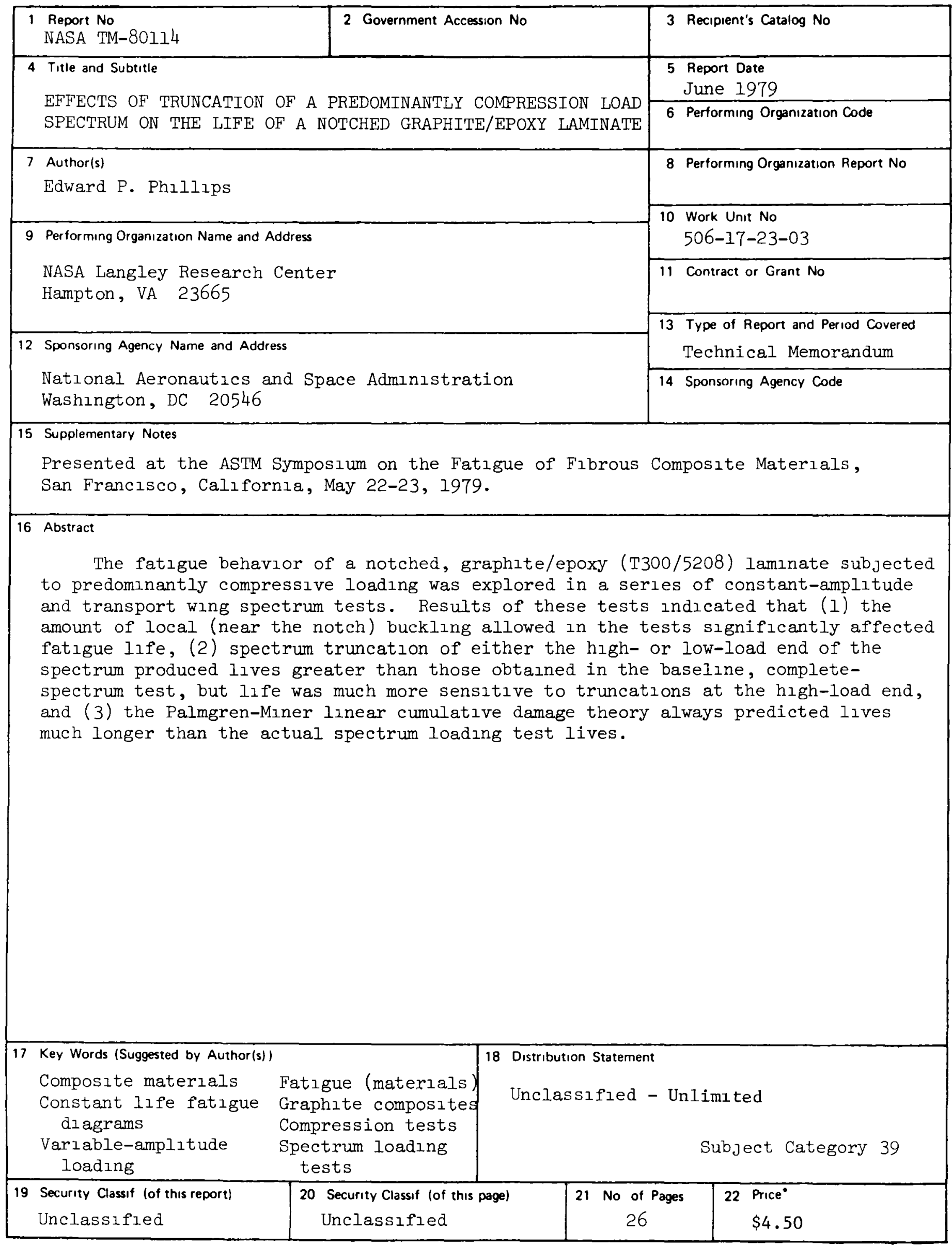

*For sale by the National Technical Information Service, Springfield Virgınıa 22161 


\section{EFFECTS OF TRUNCATION OF A PREDOMINANTLY \\ COMPRESSION LOAD SPECTRUM ON THE LIFE OF A \\ NOTCHED GRAPHITE/EPOXY LAMINATE}

Edward P. Phıllıps

NASA Langley Research Center

Hampton, Virginıa 23665

ABSTRACT

The fatıgue behavior of a notched, graphıte/epoxy (T300/5208) lamınate subjected to predominantly compressıve loading was explored in a serıes of constant-amplitude and transport wing spectrum tests. Results of these tests indicated that ( 1 ) the amount of local (near the notch) buckling allowed in the tests sıgnificantly affected fatıgue life, (2) spectrum truncation of elther the high- or low-load end of the spectrum produced lives greater than those obtalned in the baseline, complete-spectrum test, but life was much more sensitive to truncations at the high-load end, and (3) the Palmgren-Miner Iinear cumulatıve damage theory always predicted lives much longer than the actual spectrum loading test lives. KEY WORDS composite materials, fatıgue (materials), compression tests, graphite composıtes, epoxy laminates, constant lıfe fatıgue diagrams, varıable amplıtude loadıng tests, spectrum loadıng tests

INTRODUCTION

In most alrframe development programs, the results of structural fatıgue tests are used to decıde if the structure satısfles the fatıgue 
Ilfe desıgn requirement. Years of experience with tests on aluminum coupons and structures have led to satisfactory procedures for defining sultable test load spectra, that is, spectra which yield a representatıve life estımate in a reasonably short test tıme. In partıcular, a general understanding of the effects of truncating load spectra at the high- and low-load levels has evolved. For composite materials, however, a similar base of test experience has not yet been accumulated.

The current work was undertaken to explore (1) the effect of spectrum truncations on the fatigue Infe of notched, quasi-lsotropic graphite/ epoxy coupons and (2) the capability of the Palmgren-Miner linear cumulative damage theory to predict the truncation effects. Since cyclic compressive loading is generally more detrimental to composites than cyclıc tension [1-3], a load spectrum representatıve of the upper surface of a transport wing was used in the current work. Constant-amplitude tests were conducted to explore the sensitivity of fatigue life to the amount of local (near the notch) buckling allowed in the tests and to provide data for cumulatıve damage calculations.

EXPERIMENTAL PROCEDURE

Materials and Specimens

Specımens were cut from 16-ply, [45/0/-45/90] $]_{\text {2s }}$ (quası-isotropic) sheets made from T300/5208 graphite/epoxy unidirectional tape. The cured lamınate had an average ply thıckness of $0.14 \mathrm{~mm}$, a flber volume of 
64 percent, and a vold content of 0.36 percent. Specimens were stored and tested in an ambient laboratory alr environment. Measurements taken on several speclmens during the test program indicated a 0.6 to 0.7 percent molsture content by weight.

The test specimen configuration is shown in figure 1. The central $6.35-\mathrm{mm}$ hole was made by a dlamond-coated, ultrasonically vibrating drill. Generally, this drilling procedure produced very clean hole surfaces, but some interlaminar crackıng was detected between the first two plies on the drill exit surface of most of the specimens. Nondestructive examinations showed the depth of the delaminations did not exceed $0.3 \mathrm{~mm}$, and subsequent test observations indicated the delaminations did not play a signiflcant role in the fallure process.

Test Machınes

Specimens were tested to complete rupture in axlal-load, closed-loop, servohydraulıc testıng machınes having about $45 \mathrm{kN}$ force capacity. Constantamplıtude and varıable-amplitude tests were run at a nearly unıform loading rate so that loading frequency ranged from about 3 to $20 \mathrm{~Hz}$ depending upon load amplitude. Load sequences were generated by a small, on-line digital computer.

Load Spectra

The standardized test TWIST (Transport WIng Standard Test) [4] was used in the spectrum loading tests. TWIST was developed jointly by the 
Laboratorium für Betriebsfestıgkeıt in Germany and the Natıonal Lucht-en Ruimtevaartlaboratorium in The Netherlands. A list of the most significant features of this test is given in table $I$ and a tabulation of the load spectrum is given in table 2. In addition to the baseline TWIST spectrum, several truncated versions were used. The truncated versions were created by deleting the following load levels: (1) the lowest, (2) the two lowest, (3) the four lowest, (4) the two highest, and (5) the four highest and the lowest. In the truncation process, flights were never completely eliminated even though all of the flight loads included in the baseline version of the flight were scheduled to be deleted (see tables 1 and 2). For such flights, the truncated version of the flight consisted of a ground-air-ground cycle which was bounded by the ground load and the highest flight load in the baseline version of the flight (see fig. 2). The sequence of flight types remalned the same as the baseline TWIST sequence in all tests, but the sequence of loads within flights changed as a result of each spectrum truncation.

Specımen Antıbucklıng Procedure

Specimens were restralned from column buckling durıng compressive loading by sandwlching the specimen between two aluminum plates (coated with a trifluoroethylene resin plastic). This antlbuckling procedure was chosen because It was the simplest of the methods described in the literature $[1-3,5,6]$ and because no method had a clear advantage. In the instances where the "plate-sandwlch" antibuckling procedure was used in studies reported in the literature $[1,3,5]$, the degree to which local 
(near the notch) buckling was allowed varled over a wlde range. That is, elther the plates covered the entire specimen surface or some portion of the plates was cut away to free the test section. Because the size of the windows (cutouts) in the antibuckling plates could reasonably be expected to influence fatigue life, prelimınary tests were conducted to explore the magnitude of the effect.

RESULTS AND DISCUSSION

Specımen Buckling Restraint Tests

The four antibuckling plate configurations used in the tests and correspondıng median test lives for one stress level are shown in flgure 3 . Test results are tabulated in table 3. As expected, the more specimen surface covered by the antıbuckling plates, the longer the fatigue infe. The life for tests in which the antıbuckling plates had no window was about 30 times that for tests in which the windows were $32-\mathrm{mm}$ wide and elther 32- or 64-mm long. For higher compressıve loadıng, the difference in lives was even more pronounced. The results in figure 3 Illustrate the need to consider the influence of the antıbuckling procedures in making comparisons among compressive-loading fatıgue data from the literature.

The antibucklıng plates having a 32- by 32-mm window were selected for all subsequent tests in the current work. This selection was based on the feeling that local buckling associated with delamination around the hole should not be restrained, but that the specimen should be restralned from 
general-section buckling so that testing can cover the full material strength range. In the current tests, the delamination zone exceeded the 19-mm window size in many tests but rarely exceeded the 32-mm size. The choice of any antibuckling procedure is, of course, rather arbitrary in the sense that none of the procedures will realıstıcally simulate buckling conditions in all structural configurations.

Constant-Amplitude Tests

Constant-amplitude tests were conducted at several $R$ values $\left(R=\frac{m \_n ı m u m ~ s t r e s s}{m a x ı m u m ~ s t r e s s}\right)$ to provide data for the cumulative damage calculations. Results of the tests are tabulated in table 4 and shown in figure 4 in the form of a constant life dlagram. Results of tension and compression static strength tests of this specimen conflguration are also plotted in figure 4. As expected, the constant 11 fe diagram shows that compressive mean stresses had a deleterious effect on fatigue life. All of the constant IIfe IInes proceed down and to the left from the $\mathrm{R}=-1$ Inne (that $1 \mathrm{~s}$, In the compressive mean stress half of the diagram). This trend in the constant Ilfe lines means that for a constant alternating stress, the higher the compressive mean stress, the lower the life. By contrast, the opposite trend is evident over at least a portion of the tensile mean stress half of the diagram; that is, the higher the tenslle mean stress, the higher the IIfe. In general, the trends in the data show that the laminate tested in the current program is more susceptıble to compressive fatıgue loading than to tensile fatıgue loadıng. 
The fallure process in all compression-dominated tests was progressive delamination followed by fallure in a crippling mode. In most tests, the surface plies split and buckled near the hole at about 10 to 20 percent of the Iıfe. The shadow Moıré [7] photograph ın fıgure 5 lllustrates this fallure mode. The area of out-of-plane displacement is outlined by the closely spaced fringes near the hole. The more widely spaced fringes away from the hole are "Initıal condition" fringes and do not represent out-of-plane displacement of the specimen. Durıng each test, delaminations initiated and grew at all of the ply interfaces at the hole. The extent of the delaminated zone near the end of a test (at 93 percent of the $11 \mathrm{fe}$ ) is shown in the dye-enhanced $x$-ray radıograph [8] in figure 6 . At equal IIves, the extent of delamination at rupture (especially of the surface ply) was greater for tests wzth the greater tensıle stress in the loading cycle. This is lilustrated in the photograph of falled specimens in figure 7 .

Spectrum Loadıng Tests

The flight mean stress (spectrum reference level, see Table 2) in the current tests was $-111 \mathrm{MPa}$ (based on the gross section). This stress level was chosen because it produced test lives representatıve of transport alrcraft design goals (about 60,000 flights of the baseline spectrum). A few preliminary tests at a flight mean stress of $-95 \mathrm{MPa}$ had produced lives of about $10^{6}$ flights. At the $-111 \mathrm{MPa}$ flight mean stress, the maximum stress in the baseline spectrum was $-289 \mathrm{MPa}$, or 89 percent of the median compressive 
static strength. Corresponding gross-section strain levels for the flight mean and maximum stresses in the spectrum were 0.002100 and 0.005450 , respectively. The appearance of the fallures and the extent of delamination" at fallure in the spectrum loading tests were simllar to those for predominantly compression constant-amplitude tests at the same maximum compressive load.

The results of the tests to explore truncation effects are shown in figure 8 and tabulated in table 5. A comparıson of the median lıves (in flights) indicates that truncation of the spectrum at elther the high- or low-load end produced lives greater than those obtalned in the baseline spectrum test. However, life was much more sensıtıve to truncatıons at the high-load end. Omission of the four highest load levels plus the lowest level produced lives eleven times the baseline spectrum IIfe. With these omissions, the effect on life appears to be largely due to omission of the high loads (which constitute less than 0.007 percent of the total number of load cycles in the spectrum) since omission of the lowest load alone did not produce lives longer than the baseline spectrum. Indeed, omission of the four lowest load levels produced lives only two times the baseline spectrum life even though the omitted load cycles constitute more than 99 percent of the loads in the baseline spectrum.

In defining the test spectrum for composite wing structures, the data in flgure 8 suggest that the high-load end of the spectrum should not be truncated to the same extent as has been the practice for metallic structures. On the other hand, truncation of the low-load end of the spectrum shows 
promise for achieving large reductions in test time without significantly changing the test result.

IInear Cumulatıve Damage Evaluation

To explore the usefulness of the Palmgren-Miner linear cumulatıve damage theory for composite applications, the medlan llves from the spectrum loading tests were compared to the corresponding lives calculated from the theory. The cumulative damage calculations were based on the constant-amplitude data represented in figure 4 and on the "rainflow" method [9] of defining the random load history in terms of constant-amplitude cycles.

Predicted and measured lives are plotted in flgure 9 for comparison. As can be seen, the linear damage theory always predicted longer lives than the actual test lives, that is, predictions were always on the unsafe side. The ratios of predicted to test life ranged from 6.6 to 19.8. Rosenfeld and Huang [1] and Schutz and Gerharz [3] have reported the same trend for tests on other graphite/epoxy lamınates using fighter-wing load spectra.

The results in figure 9 also show that the linear damage theory failed to predict the trend toward longer life for progressively larger truncations of the spectrum at the low-load end. For truncations at the high-load end of the spectrum, however, the theory did predict the correct trend in life.

CONCLUDING REMARKS

The fatigue kehavior of a notched, graphlte/epoxy (T300/5208), $[45 / 0 /-45 / 90]_{2 s}$ lamınate subjected to predomınantly compressive loadıng was 
explored in a serıes of constant-amplitude and transport wing spectrum tests. These exploratory tests support the following conclusions and observations:

1. The amount of local (near the notch) buckling allowed in the tests sıgniflcantly affected fatıgue life. This result indicates that the influence of antibuckling procedures used in a test must be accounted for to make meaningful comparısons among compressıve-loading fatıgue data from the literature.

2. Spectrum truncation at elther the hlgh- or low-load end of the spectrum produced lives greater than those obtalned in the baseline, complete-spectrum test. However, IIfe was much more sensitive to truncations at the high-load end. The results suggest that in defining test spectra for composite wing structures, the high-load end of the spectrum should not be truncated to the same extent as has been the practice for metallic structures. Also, truncation of the low-load end of the spectrum shows promise for achleving large reductions in test time without significantly changing the test result.

3. The Palmgren-Miner linear cumulatıve damage theory always predicted lives much longer than the actual spectrum loading test lives; that is, predictions were always on the unsafe side. However, the theory predicted the correct trends for effects of truncating the high-load end of the spectrum.

\section{REFERENCES}

[1] Rosenfeld, M. S.; and Huang, S. L.: Fatıgue Characterlstics of Graphite/ Epoxy Laminates Under Compression Loading. Technical Papers, Volume A, Amerıcan Institute for Aeronautics and Astronautıcs, Inc., New York, 1977, pp. 423-427.

[2] Ramani, S. V.; and Wllliam, D. P.: Notched and Unnotched Fatıgue Behavior of Angle-Ply Graphite/Epoxy Composites. Fatigue of Fllamentary Composite Materials, ASTM STP-636, Amerıcan Soclety for Testing and Materıals, 1977, pp. $27-46$. 
[3] Schutz, D.; and Gerharz, J. J.. Fatıgue Strength of a Fibre-Reinforced Material. Composites, vol. 8, no. 4, October 1977, pp. 245-250.

[4] de Jonge, J. B.; et al.: A Standardized Load Sequence for Flight Simulation Tests on Transport Aircraft Wing Structures. NLR-TR-73029U, National Lucht-en Ruimtevaartlaboratorlum, Amsterdam, The Netherlands (also LBF-Berıcht-FM-106, Laboratorıum fur Betriebsfestigkeıt, Darmstadt, German Federal Republic), 1973.

[5] Walter, R. W.; et al.: Desıgning for Integrity in Long Lafe Composite Alrcraft Structures. Fatigue of Fllamentary Composite Materials, ASTM STP-636, Amerıcan Soclety for Testing and Materials, 1977, pp. 228-247.

[6] Ryder, J. T.; and Walker, E. K. . Effect of Compression on Fatigue Properties of a Quasi-Isotroplc Graphite/Epoxy Composite. Fatıgue of Fllamentary Composite Materlals, ASTM STP-636, American Soclety for Testing and Materials, 1977, pp. 3-26.

[7] Theocarıs, P. S. Molre Frınges of Isopachics. J. of Sc. Instruments, vol. 41, no. 3, 1964, pp. 133-138.

[8] Chang, F. H.; et al.: Application of a Special X-Ray Nondestructive Testing Technıque for Monıtoring Damage Zone Growth in Composite Laminates. Composite Reliabllity, ASTM STP-580, American Society for Testıng and Materials, 1975, pp. 176-190.

[9] Endo, T., et al.. Damage Evaluatıon of Metals for Random or Varying Loading - Three Aspects of Rain Flow Method. Proceedings of the 1974 Symposium on Mechanical Behavior of Materials, Volume I, The Society of Materıals Science, Kyoto, Japan, August 21-24, 1974, pp. 371-380. 
TABLE 1 - Description of TWIST (Transport WIng Standard Test).

\section{Significant Features}

- Flight-by-flight loading.

- Constant flight mean load.

- All ground loads represented by a single load event equal to minus one-half the flight mean load.

- Each flıght load reversal occurred at 1 of 20 dıscrete levels; 10 levels above the flight mean and 10 levels below the flight mean (see rable 2).

- Ten flight types (severities)--each characterızed by the number of load levels involved and the number of occurrences of each level.

- Sequence of $\mathrm{f}^{\prime l}$ light types and sequence of loads within each flight determined by random draw without replacement.

- Random draw of flight loads restricted so that successive loads must generate a mean-level crossing, but no other restrictions on magnitudes of successive loads, that Is, the sequence is generated In the random half-cycle fashion.

- Load sequence repeats after $4000 \mathrm{fl}$ lghts, that Is, the block length is 4000 flights. 
TABLE 2 - Frequency of occurrence of flight types and load cycles within each flight in TWIST.

\begin{tabular}{|c|c|c|c|c|c|c|c|c|c|c|c|c|}
\hline \multirow[b]{2}{*}{$\begin{array}{l}\text { Flight } \\
\text { type }\end{array}$} & \multirow{2}{*}{$\begin{array}{l}\text { Frequency of occurrence } \\
\text { of each flight type in } \\
\text { one block of } 4000 \\
\text { flights }\end{array}$} & \multicolumn{10}{|c|}{$\begin{array}{l}\text { Frequency of occurrence of flight load cycles } \\
\text { at the ten alternating load levels }\end{array}$} & \multirow[t]{2}{*}{$\begin{array}{l}\text { Total number of } \\
\text { cycles per flight }\end{array}$} \\
\hline & & $1.60^{\mathrm{b}}$ & 1.50 & 1.30 & 1.15 & .995 & 0.84 & 0.685 & 0.53 & 0.375 & 0.222 & \\
\hline A & 1 & 1 & 1 & 1 & 4 & 8 & 18 & 64 & 112 & 391 & 900 & 1500 \\
\hline B & 1 & & 1 & 1 & 2 & 5 & 11 & 39 & 76 & 366 & 899 & 1400 \\
\hline C & 3 & & & 1 & 1 & 2 & 7 & 22 & 61 & 277 & 879 & 1250 \\
\hline D & 9 & & & & 1 & $I$ & 2 & 14 & 44 & 208 & 680 & 950 \\
\hline$E$ & 24 & & & & & $I$ & 1 & 6 & 24 & 165 & 603 & 800 \\
\hline$F$ & 60 & & & & & & 1 & 3 & 19 & 115 & 512 & 650 \\
\hline G & 181 & & & & & & & 1 & 7 & 70 & 412 & 490 \\
\hline $\mathrm{H}$ & 420 & & & & & & & & 1 & 16 & 233 & 250 \\
\hline I & 1090 & & & & & & & & & 1 & 69 & 70 \\
\hline $\mathrm{J}$ & 2211 & & & & & & & & & & 25 & 25 \\
\hline \multicolumn{2}{|c|}{$\begin{array}{l}\text { Total number of load cycles per } \\
\text { block of } 4000 \text { flights }\end{array}$} & $I$ & 2 & 5 & 18 & 52 & 152 & 800 & 4170 & 34800 & 358665 & \\
\hline \multicolumn{2}{|c|}{$\begin{array}{l}\text { Cumulative number of load cycles } \\
\text { per block of } 4000 \text { flights }\end{array}$} & 1 & 3 & 8 & 26 & 78 & 230 & 1030 & 5200 & 40000 & 398665 & \\
\hline
\end{tabular}

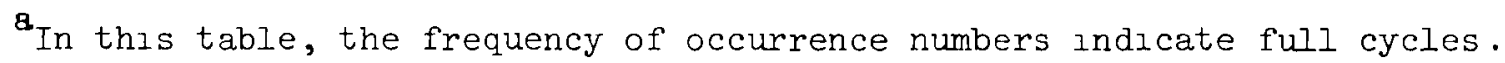

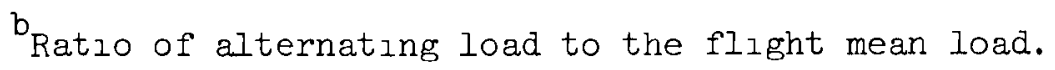


TABLE 3 - Results of tests ${ }^{2}$ to explore the effect of local buckling restraint on fatigue life.

\begin{tabular}{|c|c|}
\hline $\begin{array}{l}\text { Dimensions of windows in } \\
\text { antibuckling plates, mm }\end{array}$ & $\begin{array}{l}\text { Fatigue life, } \\
\text { cycles }\end{array}$ \\
\hline $\begin{array}{c}\text { No } \\
\text { w1ndow }\end{array}$ & $\begin{array}{lll} & 194 & 000 \\
1 & 112 & 149 \\
2 & 861 & 708 \\
5 & 881 & 792\end{array}$ \\
\hline 19 by 19 & $\begin{array}{ll}102 & 517 \\
136 & 372 \\
349 & 650\end{array}$ \\
\hline 32 by 32 & $\begin{array}{rr}61 & 914 \\
66 & 029 \\
132 & 274\end{array}$ \\
\hline 32 by 64 & $\begin{array}{rr}45 & 065 \\
55 & 742 \\
112 & 071\end{array}$ \\
\hline
\end{tabular}

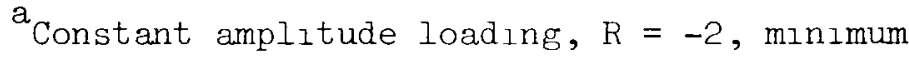
gross-section stress $=-207 \mathrm{MPa}$ 
TABLE 4 - Results of constant amplitude fatıgue tests ${ }^{a}$.

\begin{tabular}{|c|c|c|}
\hline$\left(\begin{array}{ll}\mathrm{R} \\
\text { Min. } & \text { stress } \\
\text { Max. } & \text { stress }\end{array}\right)$ & $\begin{array}{l}\text { Minimum } \\
\text { gross-section } \\
\text { stress, MPa }\end{array}$ & $\begin{array}{l}\text { Fatıgue } \\
\text { lıfe, } \\
\text { cycles }\end{array}$ \\
\hline \multirow{3}{*}{+3} & -289 & $\begin{array}{ll}1 & 600 \\
3 & 334\end{array}$ \\
\hline & -248 & $\begin{array}{r}737968 \\
1131736\end{array}$ \\
\hline & -207 & $\begin{array}{lll}>10 & 000 & 000 \\
>10 & 000 & 000\end{array}$ \\
\hline \multirow{4}{*}{$\infty$} & -289 & $\begin{array}{ll}1 & 298 \\
1 & 844\end{array}$ \\
\hline & -248 & $\begin{array}{ll}15 & 924 \\
78 & 132\end{array}$ \\
\hline & -207 & 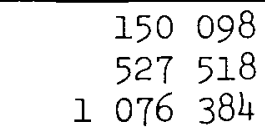 \\
\hline & -165 & $\begin{array}{llll}>10 & 000 & 000 \\
>10 & 000 & 000 \\
\end{array}$ \\
\hline \multirow{3}{*}{-5} & -289 & $\begin{array}{ll} & 392 \\
1 & 070\end{array}$ \\
\hline & -248 & $\begin{array}{l}33976 \\
43417\end{array}$ \\
\hline & -207 & $\begin{array}{l}395282 \\
546 \quad 434 \\
\end{array}$ \\
\hline \multirow{4}{*}{-2} & -289 & $\begin{array}{l}318 \\
350 \\
370\end{array}$ \\
\hline & -248 & $\begin{array}{ll}1 & 939 \\
2 & 710 \\
8 & 141\end{array}$ \\
\hline & -207 & $\begin{array}{rr}61 & 914 \\
66 & 029 \\
132 & 274\end{array}$ \\
\hline & -165 & $\begin{array}{lll}3 & 133 & 789 \\
3 & 917 & 639 \\
4 & 925 & 000 \\
\end{array}$ \\
\hline \multirow{4}{*}{-1} & -238 & 444 \\
\hline & -207 & $\begin{array}{ll}22 & 263 \\
25 & 550\end{array}$ \\
\hline & -165 & $\begin{array}{ll}247 & 012 \\
317 & 110\end{array}$ \\
\hline & -134 & $>10000000$ \\
\hline
\end{tabular}


TABLE 4 - Concluded

\begin{tabular}{|c|c|c|}
\hline $\left.\begin{array}{l}\text { R } \\
\text { Min. stress }\end{array}\right)$ & $\begin{array}{l}\text { Minımum } \\
\text { gross-section } \\
\text { stress, MPa }\end{array}$ & $\begin{array}{l}\text { Fatıgue } \\
\text { life, } \\
\text { cycles }\end{array}$ \\
\hline \multirow{2}{*}{0.5} & -119 & 123618 \\
\cline { 2 - 3 } & -103 & $\begin{array}{l}1433070 \\
3876274 \\
3954528\end{array}$ \\
\hline
\end{tabular}

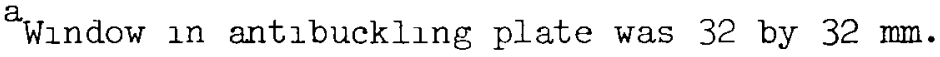


TABLE 5 - Results of the spectrum loading fatigue tests ${ }^{a}$ using the baseline and truncated spectra.

\begin{tabular}{|c|c|}
\hline $\begin{array}{l}\text { Spectrum } \\
\text { truncations }\end{array}$ & $\begin{array}{l}\text { Fatıgue } \\
\text { lıfe, } \\
\text { flights }\end{array}$ \\
\hline $\begin{array}{c}\text { None } \\
\text { (Baseline spectrum) }\end{array}$ & $\begin{array}{rr}61 & 655 \\
61 & 655 \\
65 & 655 \\
165 & 655\end{array}$ \\
\hline $\begin{array}{c}\text { Lowest load level } \\
\text { omltted }\end{array}$ & $\begin{array}{r}34855 \\
53655 \\
57655 \\
157665\end{array}$ \\
\hline $\begin{array}{c}\text { Two } \\
\text { lowest load levels } \\
\text { omltted }\end{array}$ & $\begin{array}{rr}82 & 855 \\
86 & 855 \\
118 & 855 \\
137 & 655\end{array}$ \\
\hline $\begin{array}{c}\text { Four } \\
\text { lowest load levels } \\
\text { omltted }\end{array}$ & $\begin{array}{r}34855 \\
134855 \\
137 \quad 655 \\
138 \quad 855\end{array}$ \\
\hline $\begin{array}{l}\text { Two } \\
\text { highest load levels } \\
\text { omitted }\end{array}$ & $\begin{array}{rr}49 & 652 \\
130 & 855 \\
267 & 982 \\
311 & 359 \\
\end{array}$ \\
\hline $\begin{array}{l}\text { Four } \\
\text { hlghest and the } \\
\text { lowest load levels } \\
\text { omltted }\end{array}$ & 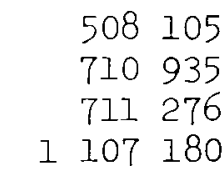 \\
\hline
\end{tabular}

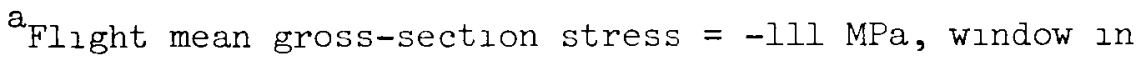
antibuckling plate was 32 by $32 \mathrm{~mm}$. 


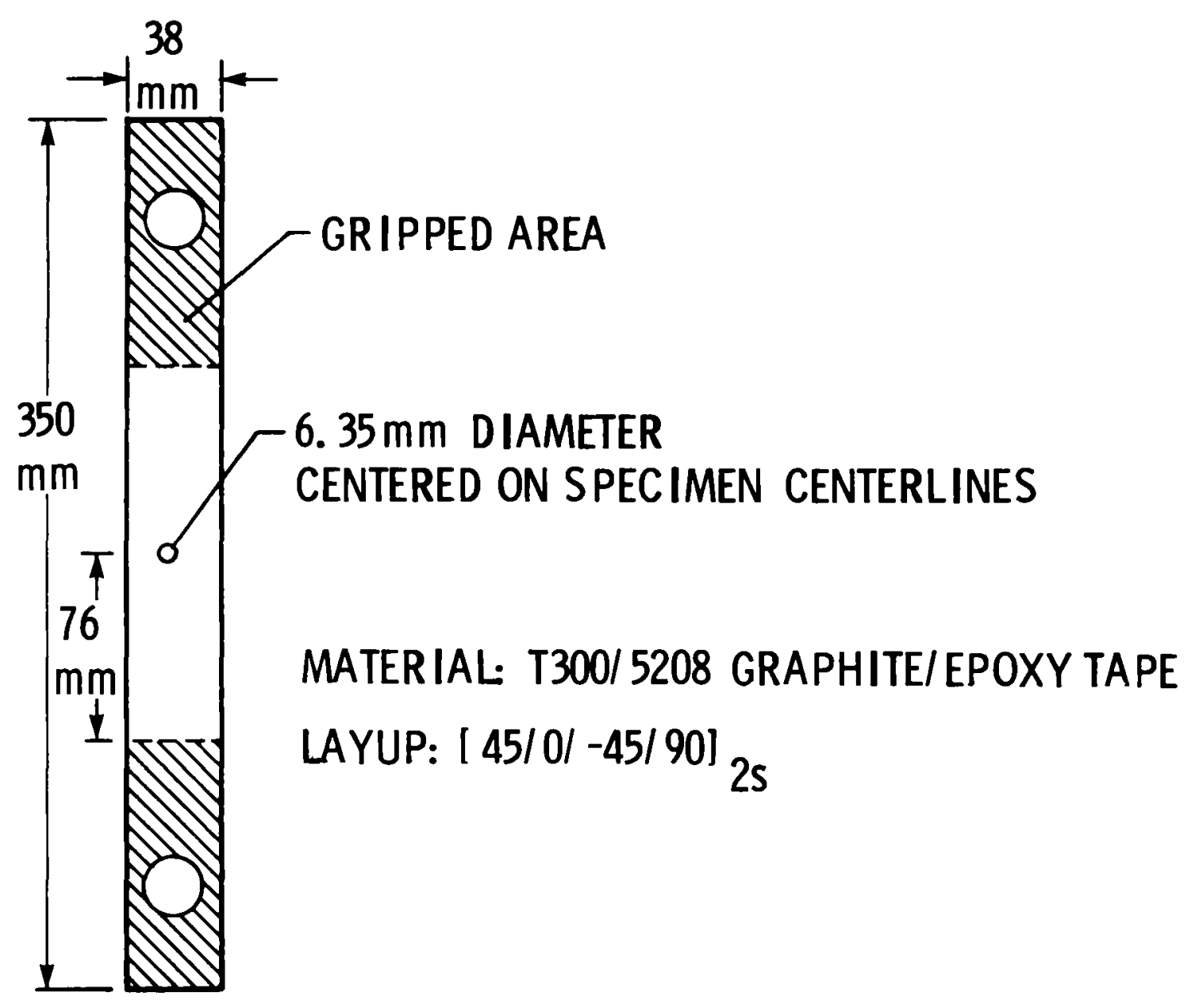

Figure 1. - Specimen configuration. 


\section{BEFORE \\ DELETION OF FLIGHT LOAD CYCLES $\quad$ DELETION OF FLIGHT LOAD CYCLES \\ AFTER}

TENSION

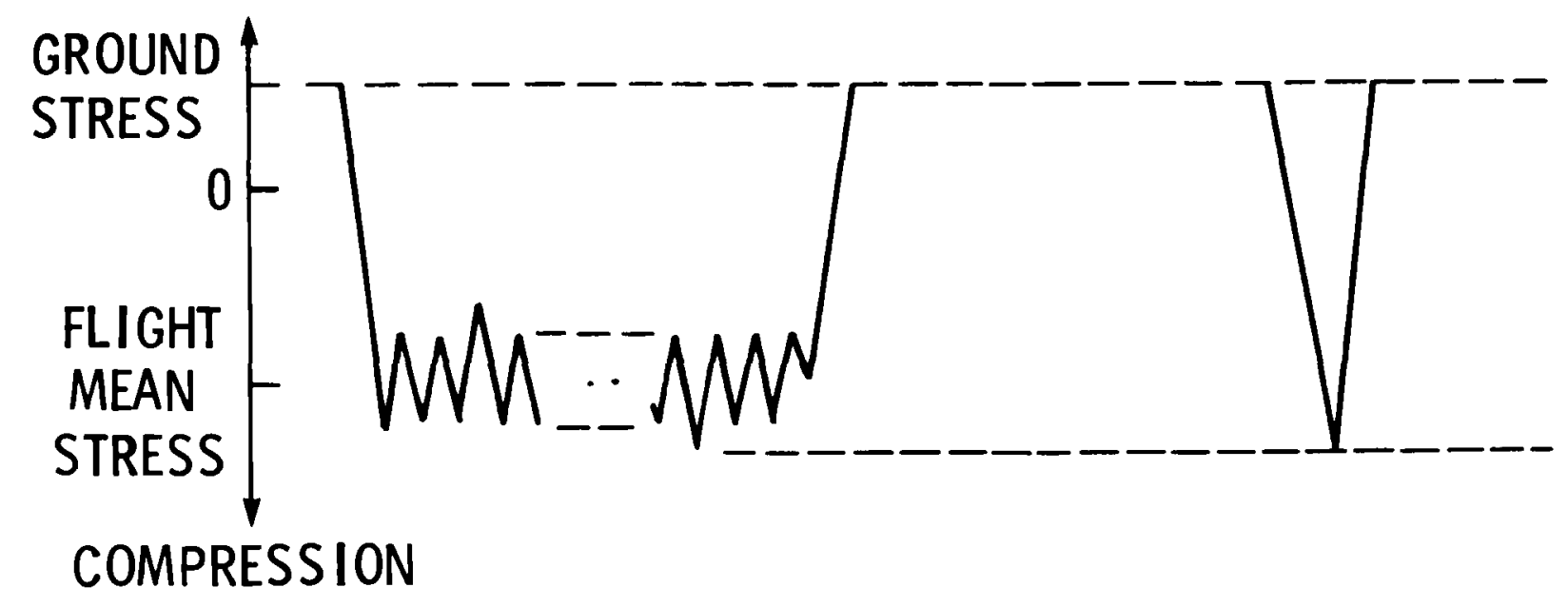

Figure 2. - Example of truncation procedure for flights in which all flight load cycles were scheduled for deletion. 


\section{TEST CONFIGURATIONS}
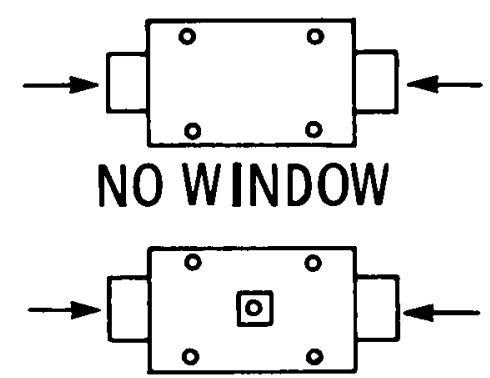

19 BY $19 \mathrm{~mm}$ WINDOW

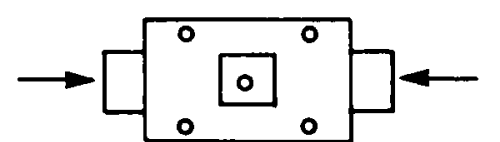

32 BY $32 \mathrm{~mm}$ WINDOW

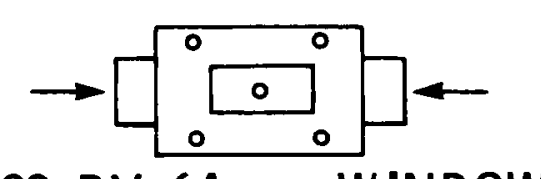

32 BY $64 \mathrm{~mm}$ WINDOW

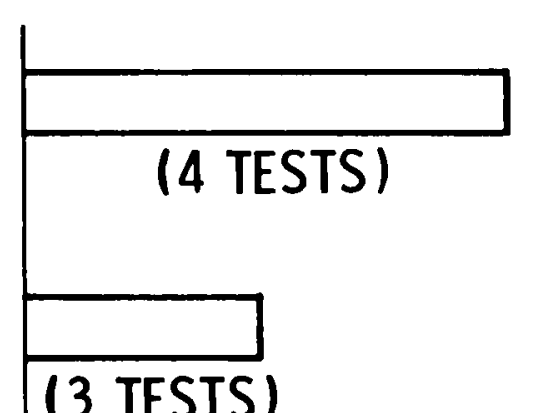

(3 TESTS)

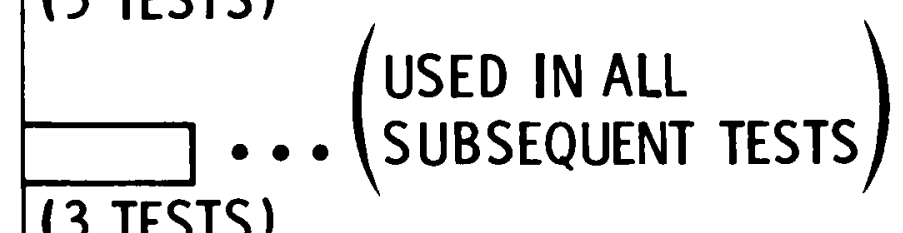

(3 TESTS)

$\longrightarrow$

(3 TESTS)

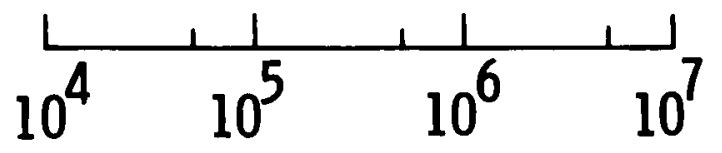

MEDIAN FATIGUE LIFE, CYCLES

Figure 3.- Effect of antibuckling-plate window size on fatigue life, (Constant amplitude, $R=-2$, minimum gross-section stress $=-207 \mathrm{MPa}$, ) 


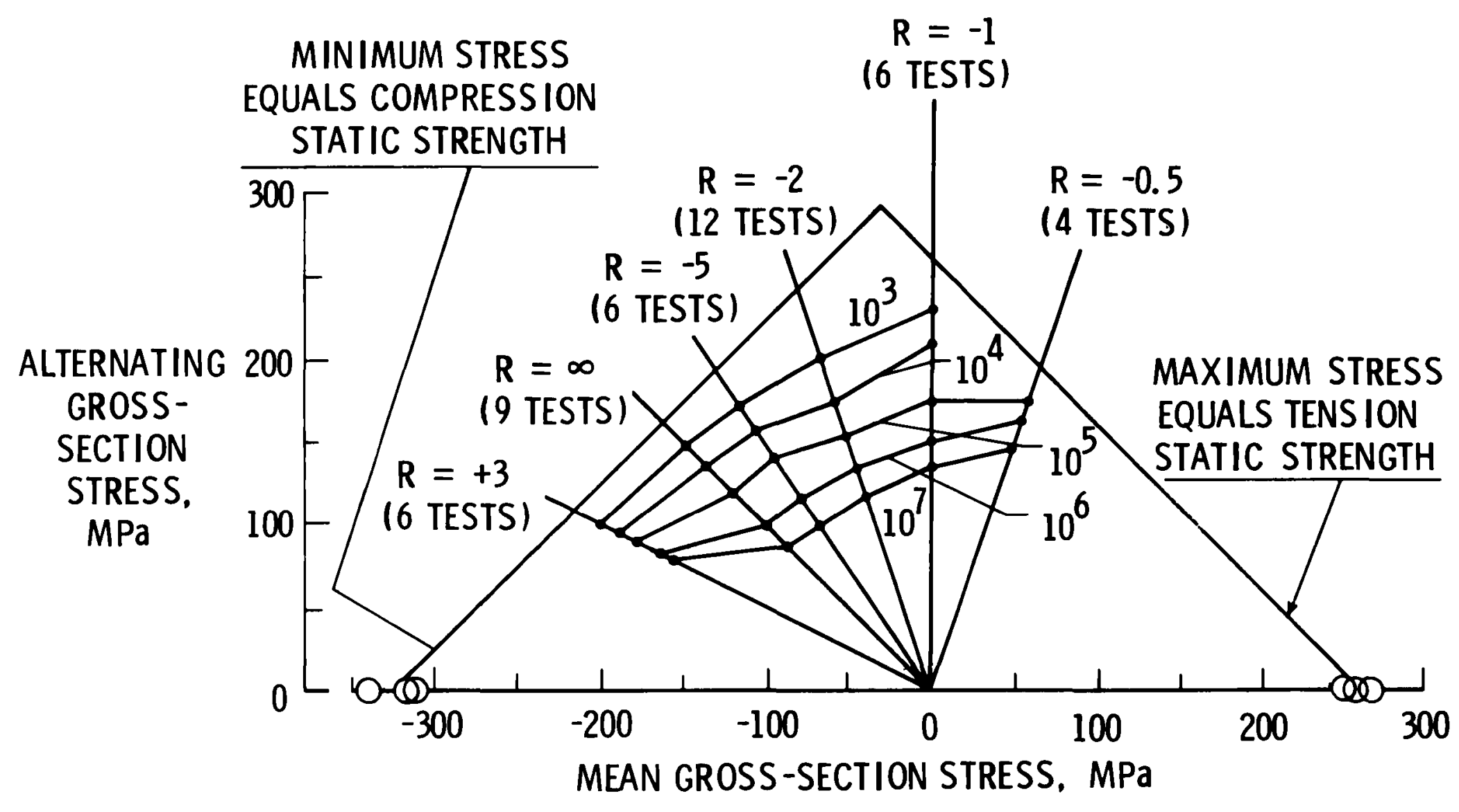

Figure 4.- Constant-life diagram constructed from the results of the constant amplitude tests, 


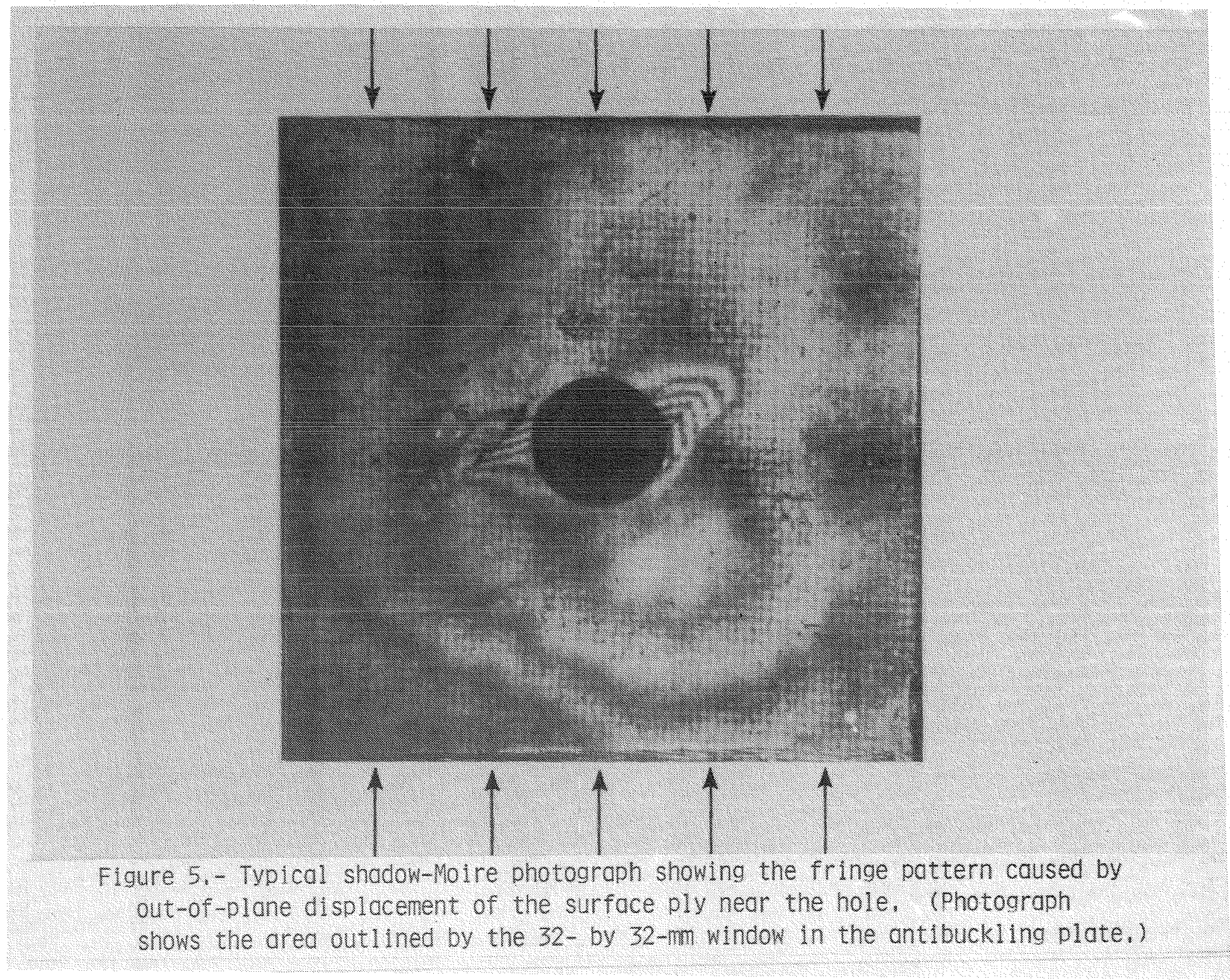




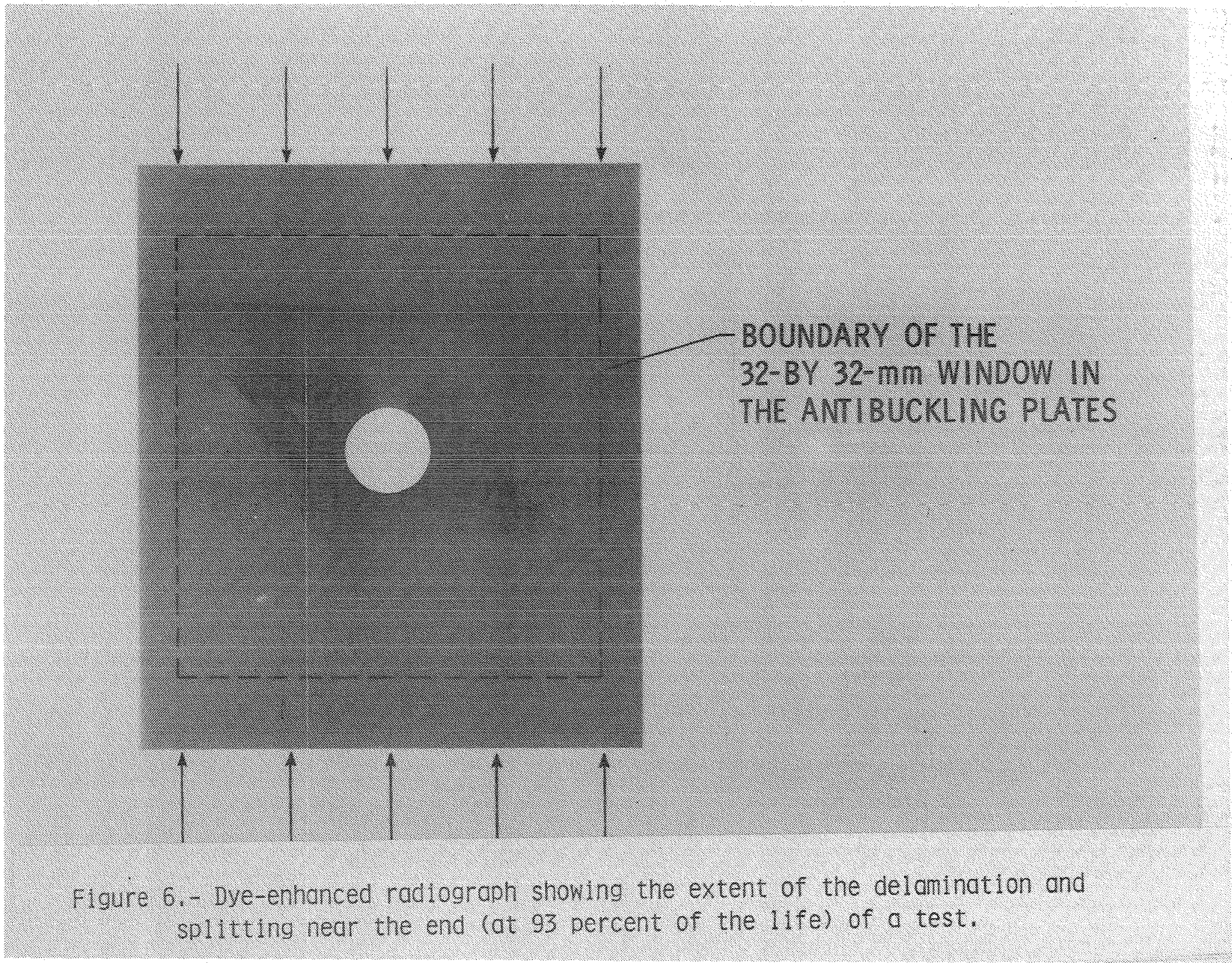




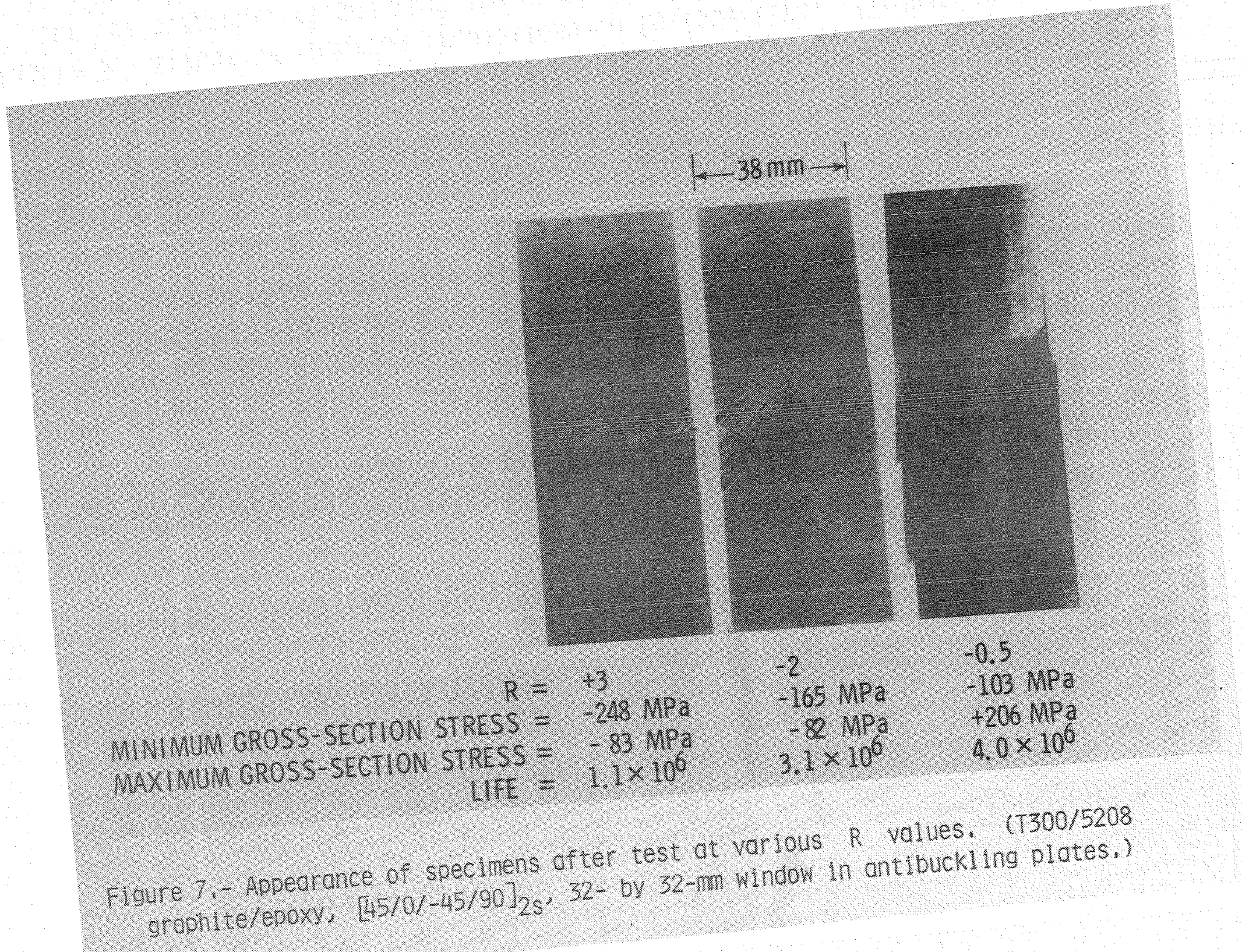




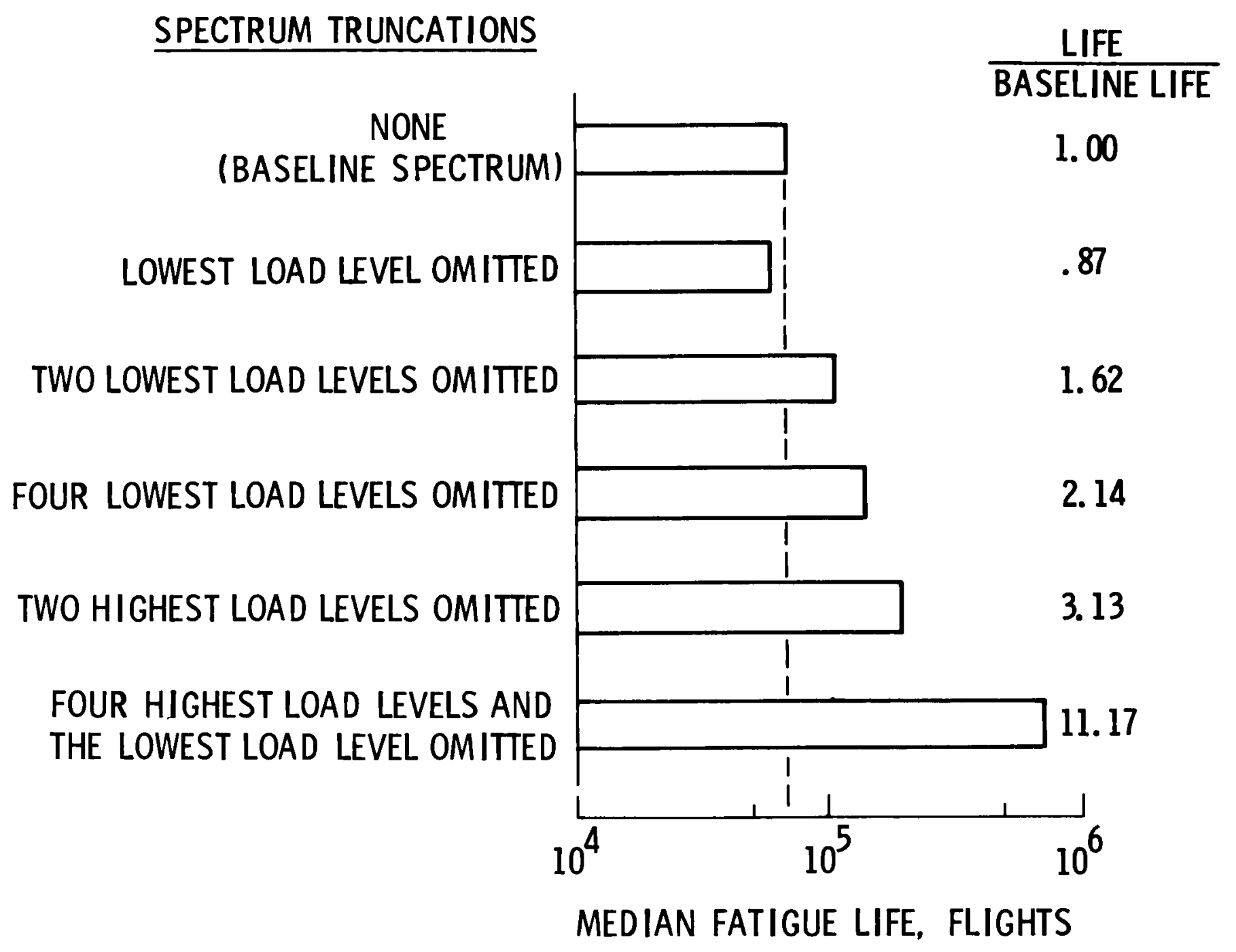

Figure 8.- Effect of spectrum truncations on fatigue life. (Transport upper-wingsurface spectrum, flight mean gross-section stress $=-111 \mathrm{MPa}$, four tests per spectrum. ) 


\section{SPECTRUM TRUNCATIONS}

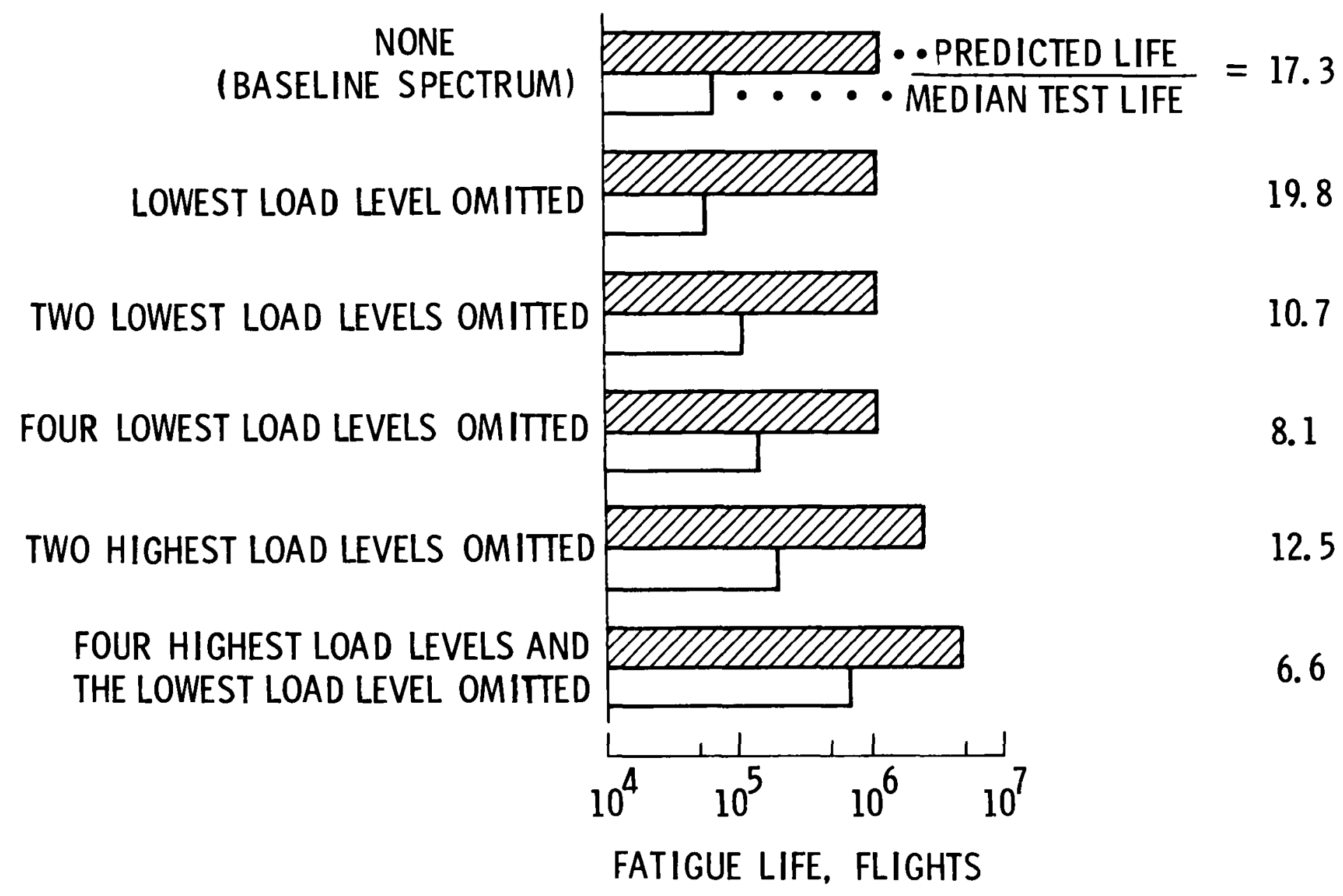

Figure 9.- Comparisons of lives predicted by the linear cumulative damage theory to actual test lives. 


\section{End of Document}

